\title{
Restoration of abandoned subtropical highland grasslands in Brazil: mowing produces fast effects, but hay transfer does not
}

\author{
Pedro Augusto Thomas ${ }^{1 *}$ (1), Gerhard Ernst Overbeck ${ }^{2,3}$ (1) and Sandra Cristina Müller ${ }^{1,2}$ (1)
}

Received: October 22, 2018

Accepted: February 28, 2019

\begin{abstract}
Subtropical Campos Sulinos grasslands, in South Brazil, are among the most biodiverse grasslands of the world. As climatic conditions lead to high productivity, disturbance are critical to maintain their diversity. Long-term exclusion, on the other hand, leads to plant species losses and changes in composition. No studies on the restoration of these grasslands after abandonment exist to date. We tested combinations of restoration techniques with the aim of increasing plant diversity in an abandoned and species-poor grassland in the South Brazilian highland region. In a bi-factorial experiment, we tested the effects of two different frequencies of mowing and of hay transfer. Mowing reduced plant cover, vegetation height, and abundance of erect grasses and shrubs, and increased species richness, diversity (Shannon diversity index) and prostrate forb and grass cover. No differences were found between mowing frequencies. Hay transfer was not effective at reintroducing species. The results of the present study provide further evidence that the reintroduction of plants is a major challenge in the restoration of subtropical and tropical grasslands. The study shows that mowing is a fast way to increase plant diversity in Campos Sulinos after long periods of abandonment.
\end{abstract}

Keywords: Andropogon lateralis, Campos Sulinos, highland grasslands, reintroduction of management, old-growth grassland, species reintroduction

\section{Introduction}

Plant diversity in grassy biomes in regions with climatic conditions that allow, at least during one season of the year, high productivity is strongly associated with the presence of disturbances such as fire and herbivory (Bond \& Keeley 2005; Veldman et al. 2015; Bond 2016). These disturbances impede biomass accumulation and reduce the height of dominant plants, thus maintaining a high diversity of herbaceous species (Bond \& Keeley 2005). Upon exclusion of these disturbances, few tussock grasses and shrubs will dominate the community, resulting in loss of herbaceous species and changes in species composition (Overbeck et al. 2005; Veldman et al. 2015; Bond 2016).

Worldwide, ecological restoration of abandoned grasslands, that is, grasslands excluded from fire and herbivory, includes reintroduction of disturbances. Mowing, controlled fire, and herbivore reintroduction are techniques commonly employed (Packard \& Ross 2005; Törok et al. 2011). If the local species pool has been reduced through longer periods of abandonment, species reintroduction may additionally be necessary. Common techniques to reintroduce plant species are direct sowing, turf transplant, hay transfer, and topsoil transfer (see reviews by Kiehl et al. 2010 and Török et al. 2011). Which of these techniques

1 Laboratório de Ecologia Vegetal, Universidade Federal do Rio Grande do Sul, 91501-970, Porto Alegre, RS, Brazil

2 Programa de Pós-Graduação em Ecologia, Universidade Federal do Rio Grande do Sul, 91501-970, Porto Alegre, RS, Brazil

3 Programa de Pós-Graduação em Botânica, Universidade Federal do Rio Grande do Sul, 91501-970, Porto Alegre, RS, Brazil

* Corresponding author: pedroathomas@hotmail.com 
(or their combinations) is most adequate depends on the specific local situation.

Subtropical Campos Sulinos grasslands, South Brazil, are among the most biodiverse grasslands of the world (Overbeck et al. 2007; Andrade et al. 2019). These grasslands are traditionally managed with grazing, and fire can be used as an additional management tool (Overbeck et al. 2007; Pillar \& Vélez 2010). When excluded from disturbances, the pattern of species loss described above is observed in Campos Sulinos grasslands (Boldrini \& Eggers 1996; Overbeck et al. 2005; Andrade et al. 2016; Koch et al. 2016; Guido et al. 2017).

Exclusion of management is not an issue in private properties in the Campos Sulinos region, as these areas that make up the larger part of Campos Sulinos grasslands - are under grazing for livestock production. However, in consequence of a still prevalent forest bias in conservation policies in Brazil, grazing and fire are often excluded in government-owned protected areas and some private protected areas (for debate see e.g. Overbeck et al. 2016; 2018). Such actions led to negative effects on biodiversity, even if biodiversity conservation is one of the aims of the protected areas. For restoration and conservation of plant diversity in these systems, reintroduction of disturbances is necessary (Pillar \& Vélez 2010; Overbeck et al. 2016; Guido et al. 2017). However, so far, no studies about reintroduction of disturbances in abandoned Campos Sulinos grasslands exists (Andrade et al. 2016), and we do not know which intensity of management reintroduction is sufficient to recover plant species diversity. We still need experimental studies to know which techniques are better to improve plant species diversity on abandoned poor-species grasslands in Campos Sulinos.

In this study, we aimed to test techniques to increase plant species diversity at an abandoned grassland sites in the highland region of Rio Grande do Sul state. Specific questions were: (1) is reintroduction of disturbances, in this case mowing, sufficient to increase plant diversity? (2) How does plant diversity respond to different frequencies of mowing? (3) Is hay transfer efficient to reintroduce species and thus additionally increase plant diversity? (4) Is reduction of a dominant species, here Andropogon lateralis, a good way to increase species diversity in abandoned grasslands? And (5) are there interactive effects of both treatments (mowing + hay transfer) on plant species diversity?

\section{Materials and methods}

\section{Study area}

Field work was carried out at a particular protected area, the Pró-Mata Center for Research and Nature Conservation (CPCN Pró-Mata, 29²8'59.90"S 50¹2'25.51”O, 930 ma. s. 1.), state of Rio Grande do Sul, South Brazil. Vegetation at CPCN Pró-Mata is a mosaic of highland Campos Sulinos grasslands and Araucaria Forest. Climate is $\mathrm{Cfb}$ (according Köppen), with precipitation of 2,250 mm/year and annual mean temperature $16^{\circ} \mathrm{C}$ (Overbeck et al. 2005).

The experimental area is situated in a grassland patch of 58 ha surrounded by forest. The area is excluded of grazing and fire since 1994, but a natural fire event occurred in summer of 2011, burning part of the patch where the experiment was installed. We do not know if the entire experimental area burnt or not, but in some places burning scars could be observed on the stems of woody plants present in the area. The grassland is characterized by a dense grass stratum of about $0.8 \mathrm{~m}$ in height and is dominated by tussock grasses (mainly Andropogon lateralis Nees). At the site of the experiment, no encroachment by larger shrubs could be observed, but presence of some grassland shrubs (mainly Calea phyllolepis Baker).

\section{Experimental design}

At the grassland patch, we randomly established five $11 \mathrm{~m}$ $\mathrm{x} 11 \mathrm{~m}$ blocks, with a distance of at least $40 \mathrm{~m}$ between them. These blocks were subdivided into four experimental units (plots) of $4.5 \mathrm{~m} \mathrm{x} 4.5 \mathrm{~m}$ each, with $1 \mathrm{~m}$ of distance to border block. Three permanent quadrats of $1 \mathrm{~m} \times 1 \mathrm{~m}$ were disposed systematically within each plot (schematic drawing in Fig. S1 in supplementary material). Inside these blocks, we conducted a fully crossed two-factorial experiment, with two factors and with two levels each, resulting in four treatment combinations.

Factor one was "Mowing". We employed two levels of frequency of mowing: (1) mowed twice (late spring 2015 and mid-autumn 2016); and (2) mowed three times (late spring 2015, late summer 2016 and mid-autumn 2016) (Fig. S2 in supplementary material shows a block at late summer of 2016). Vegetation was mowed in these seasons to reduce biomass from dominant species, especially $C 4$ grasses and shrubs, which we hypothesized would allow for the growth of smaller species. Mowing was carried on with a brush cutter and biomass was removed after the first mowing to impede that the large amounts of biomass suppressed allow vegetation development.

Factor two was "Hay Transfer", with two levels: (1) with hay transfer and (2) control (without hay transfer). Hay was cut with a brush cutter and collected with a garden rake in mid-autumn (2016) at a nearby grassland managed by fire and grazing, but excluded from disturbances for five months so that flowers and fruit could develop, and at a site close to Serra Geral National Park, in the same target vegetation type. Hay was left to dry and $500 \mathrm{~g} / \mathrm{m}^{2}$ (dry hay, mixed from both sites) was spread in each $4.5 \mathrm{~m} \mathrm{x} 4.5 \mathrm{~m}$ plot at May 2016. Hay was spread over plots one week after last mowing. Abundant species with ripe seeds at the moment of hay collection were A. lateralis, Axonopus pellitus (Nees ex Trin.) Hitchc. \& Chase, Baccharis crispa Spreng., Bulbostylis sphaerocephala (Boeckeler) C.B.Clarke, Rhynchospora tenuis 


\section{Restoration of abandoned subtropical highland grasslands in Brazil: mowing produces fast effects, but hay transfer does not}

Link, Polygala sp. L., Scleria distans Poir. and Sisyrinchium palmifolium L..

As has been demonstrated before in previous studies for Campos Sulinos, at our study site grassland vegetation without any disturbances or management for longer periods is stable and with low species richness (Overbeck et al. 2005; Baldissera et al. 2010). Thus, we opted to not install a control treatment, that is, without mowing and hay transfer. Besides that, we consider the vegetation before the experiment, at 2015, as a 'negative reference' (i.e., reference for situation without intervention) condition.

\section{Data collection}

Vegetation dynamics was analyzed in the three permanent quadrats of $1 \mathrm{mx} 1 \mathrm{~m}$ in each experimental unit, totalizing 60 quadrats $\left(60 \mathrm{~m}^{2}\right)$. The initial vegetation survey was carried out before beginning of the experiment, between May and August 2015; and the last vegetation survey in May 2017, i.e. 21 months after the initial vegetation survey and 17 months after the first mowing treatment. At all sampling events, we identified all species and registered their aboveground cover, and from these values we calculated species richness and the Shannon diversity index per plot. Species were classified into simple plant life form groups: erect forb, erect grass, prostrate forb, prostrate grass, rosette forb, and shrub.

We also recorded two structural variables in each sampling unit: vegetation height (mean of five measures per quadrat, measured at the center and four corners) and plant cover. Species cover and plant cover were estimated using a decimal scale (Londo 1976). For all analyses, the mean values of the three quadrats per experimental unit was used.

\section{Data analysis}

We assessed differences between before experiment (2015) and after experiment (2017) values of and considering all treatments for species richness, Shannon diversity index, Andropogon lateralis cover (the dominant grass), plant cover, vegetation height and plant life form groups cover with Analysis of Variance (ANOVA). Also, we evaluated the effects of $A$. lateralis and vegetation height on total species diversity to 2017 values with simple linear regressions, using always values from the respective pairs of plots sampled in 2015 and 2017. Vegetation height was used as a proxy to presence of management, thus we assess the mowing effects on diversity also by the effects of vegetation height on plant diversity.

To evaluate responses of species composition to treatments, we performed a Multivariate Analysis of Variance (MANOVA), with abundance data at 2017. Additionally, a matrix correlation (Mantel) following by significance test (by randomization with 10,000 iterations) to compare species composition matrices between 2015 and 2017 was conducted. Chord distance was used as resemblance measure to both composition matrices. Ordination by principal coordinates analysis ( $\mathrm{PCoA}$ ) was then applied to species data sets of 2017 to observe species composition patterns according to the treatments. We tested ordination axes by bootstrap resampling.

ANOVA and MANOVA considered the block level, both factors (Mowing and Hay Transfer), and interaction between factors, and were conducted with 5,000 permutations (Manly 2007) and analysis of all contrasts. Shapiro-Wilk tests were performed to test the normal distribution of data. Analyses were done using the vegan package (Oksanen et al. 2017) on the R platform (R Development Core Team 2016), and in Multiv (available at http://ecoqua.ecologia.ufrgs.br).

\section{Results}

By the end of the experiment, in 2017, we identified 51 plant species, eight more than before the experiment, in 2015 (Tab. S1 in supplementary material). No exotic species were present at both years. The full species list and their mean values can be found in Table S1 in supplementary material.

Mean species richness and Shannon diversity index per plot differed across time: both were higher in 2017 than 2015 (Tab. 1). In contrast, plant cover and vegetation height were higher before conduction of the treatments, in 2015 (Tab. 1). Neither the mowing factor (two or three events) nor the hay transfer factor (with or without hay transfer) affected any of these variables when data were analyzed using only 2017 data ( $p>0.05$; Table S2 in supplementary material).

Table 1. Mean values and standard deviation of response variables between 2015 and 2017. ns p > 0.05; ${ }^{*} \mathrm{p}<0.05 ;{ }^{* *} \mathrm{p}<0.01$; $^{* * *} \mathrm{p}<$ 0.001 . Values correspond to mean value of three quadrats $\left(1 \mathrm{~m}^{2}\right)$ per experimental units. Overall means (across treatments) are given for each sampling date as no significant differences were found between factor levels (see text).

\begin{tabular}{|c|c|c|c|c|}
\hline & & 2015 ( \pm SD) & 2017 ( \pm SD) & \\
\hline \multirow{2}{*}{ Diversity } & Richness (\#) & $12.20(4.16)$ & $16.40(4.45)$ & \multirow{2}{*}{$\begin{array}{l}* * * \\
* * *\end{array}$} \\
\hline & Shannon diversity index & $1.28(0.26)$ & $1.49(0.19)$ & \\
\hline \multirow{3}{*}{ Structure } & A. lateralis cover (\%) & $52.13(14.27)$ & $49.33(8.20)$ & ns \\
\hline & Plant cover $(\%)$ & $94.60(4.05)$ & $77.25(7.36)$ & $* * *$ \\
\hline & Vegetation height $(\mathrm{cm})$ & $70.29(9.90)$ & $26.15(4.39)$ & *** \\
\hline \multirow{6}{*}{$\begin{array}{l}\text { Plant Life } \\
\text { Form }\end{array}$} & Erect forb cover (\%) & $3.82(6.49)$ & $4.18(2.04)$ & ns \\
\hline & Erect grass cover (\%) & $75.57(8.39)$ & $68.86(6.69)$ & ** \\
\hline & Prostrate forb cover (\%) & $0.72(1.09)$ & $1.63(2.04)$ & $*$ \\
\hline & Prostrate grass cover (\%) & $0.50(0.84)$ & $2.86(2.26)$ & $* * *$ \\
\hline & Rosette forb cover (\%) & $0(0)$ & $0.17(0.75)$ & ns \\
\hline & Shrub cover (\%) & $18.64(6.58)$ & $11.03(5.26)$ & $* *$ \\
\hline
\end{tabular}

Andropogon lateralis was the species with highest contribution to plant cover at 2015 and 2017 (Tab. 1), without difference across years 2015 and $2017(p=0.411)$. Linear regressions of Shannon diversity index for 2017 on 
A. lateralis cover (Fig. 1A) and vegetation height (Fig. 1B) revealed significant negative relations.

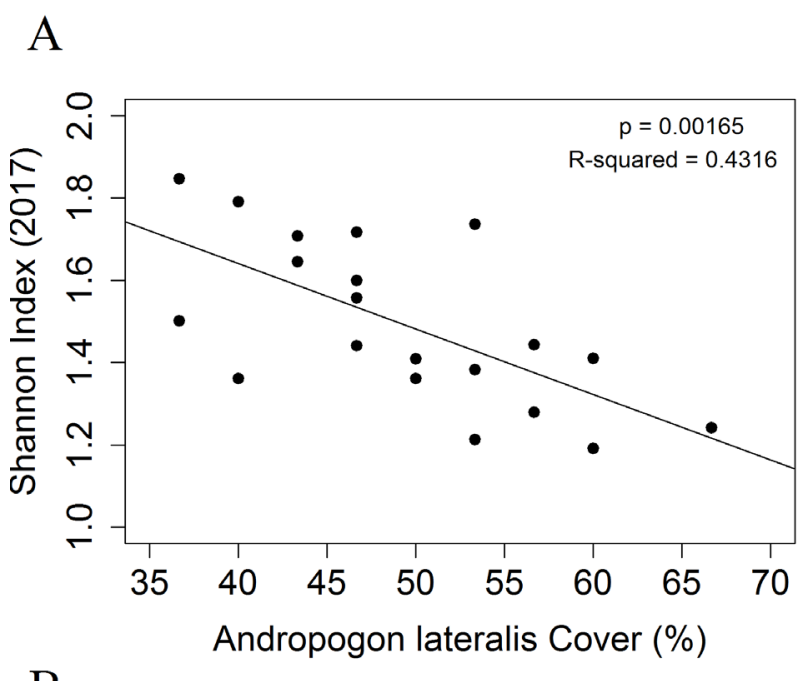

B

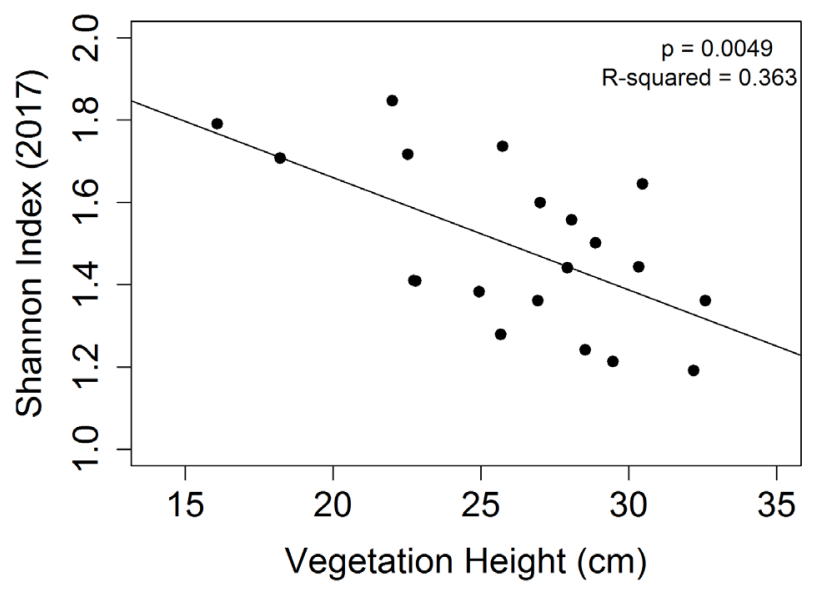

Figure 1. Linear relationships of 2017 Shannon diversity index and Andropogon lateralis cover $(\mathbf{A})$ and vegetation height (B).

Comparing cover of plant life forms from 2015 to 2017, cover of prostrate forbs and prostrate grasses showed an increase, while erect grasses and shrubs decreased (Tab. 1). Erect forbs and rosette forbs did not differ ( $p>0.05$; Tab. 1) between 2015 and 2017. Although those life forms have differed in their overall values between 2015 and 2017, treatments had no effects on 2017 cover of these life forms groups ( $p>0.05$ ) (Tab. S2 in supplementary material).

The Mantel matrix correlation indicated a low correlation ( $\mathrm{p}=0.151$ ) between species composition matrices of both years (2015 and 2017), without significance $(p=0.224)$, evidencing the effect of the experiment on the vegetation structure. According to MANOVA results, treatments did not affect species composition in 2017 (Mowing Factor, Hay Transfer Factor and interaction $\mathrm{p}>0.05$; Tab. S2 in supplementary material). Likewise, no clear relation between species composition distribution patterns and the treatments can be seen in the ordination diagram of 2017 community data (Fig. 2).

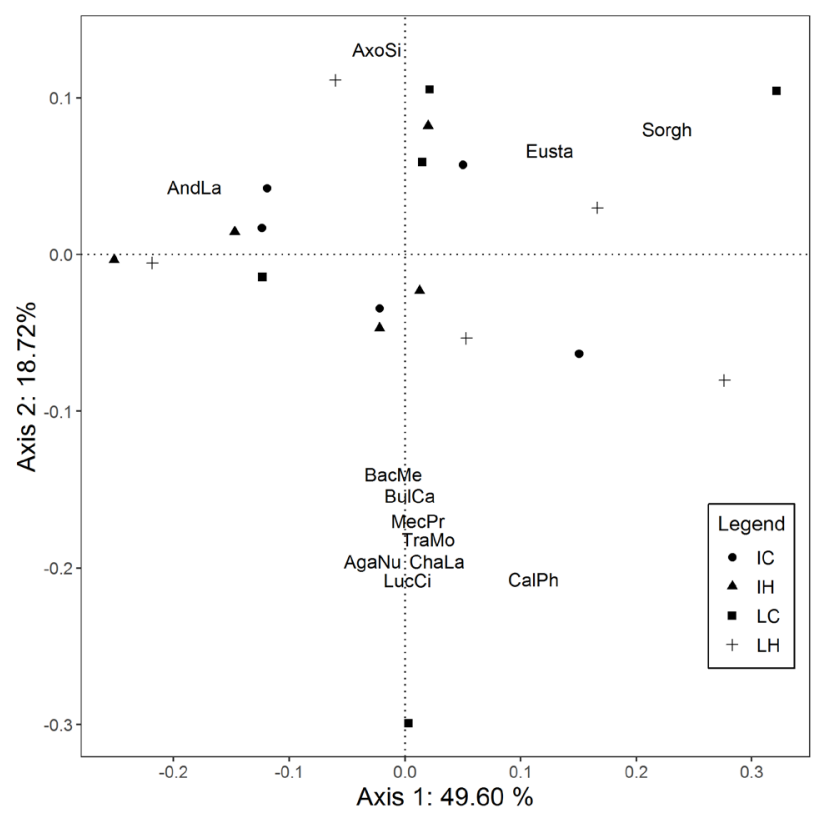

Figure 2. Ordination diagram (Principal Coordinate Analyses), considering species abundance and Chord distance as measure of plots similarity. Symbols represent the combination of treatments: low mowing intensity, without hay transfer (LC); low mowing intensity, with hay transfer (LH); intense mowing, without hay transfer (IC); intense mowing, with hay transfer (IH). Species with 0.50 or more of correlation with one of the two axes are shown: AgaNu, Agarista nummularia; AndLa, Andropogon lateralis; AxoPe, Axonopus pellitus; BacMe, Baccharis mesoneura; BulCa, Bulbostylis capillaris; CalPh, Calea phylollepis; ChaLa, Chascolytrum lamarkianum; Eusta, Eustachys sp.; LucNi, Lucilia nitans; MecPr, Mecardonia procumbens; Sorgh, Sorghastrum sp.; TraMo, Trachypogon montufari.

\section{Discussion}

Our study in abandoned grasslands showed the effect of mowing treatments on increasing plant diversity (species richness and Shannon diversity index) in a short time period (21 months). However, neither different mowing frequencies (two or three mowing events) nor hay transfer (with or without hay transfer) showed specific effects on any variable measured or species composition at 2017. Grasslands without disturbances show a general lower diversity than managed grasslands (Overbeck et al. 2005; Baldissera et al. 2010; Andrade et al. 2016; Koch et al. 2016) and, as hay transfer was ineffective in our study, observed results indicate that differences in vegetation before and after treatments are responses to the reintroduction of disturbance by mowing, irrespective of its frequency. Mowing twice in the period of 17 months was enough to increase diversity on this grassland excluded from recurrent disturbances at a long time, mowing three times did not lead to additional effects. 
Reduction of vegetation height by mowing creates conditions of less competition for space and light for plant species. This allows the establishment of new species and the increase in cover of species that were there before with a little cover. Our results are in line with to management reintroduction studies (mowing and/or burning) in other grassland ecosystems in the world (Maron \& Jefferies 2001; Maccherini \& Santi 2012; Nagata \& Ushimaru 2016; Koyama et al. 2017). Nonetheless, even after our treatments, plant diversity in our plots still is rather low compared to other sites under management or with still shorter periods of abandonment in highland grasslands of Campos Sulinos (mean values of 20 to 25 species per $1 \mathrm{~m} 2$ plot; see Andrade et al. 2016).

Besides vegetation height reduction, mowing also reduced the cover of erect grasses and shrubs, which possibly contributed to the small, but still discernible increase in cover of prostrate forbs and grasses. An example is Dichanthelium sabulorum, a widely distributed prostrate grass that was present in the plots before reintroducing the management, but was more abundant in 2017. On the other hand, on the short term, neither erect nor rosette forbs had their cover increased, even with the release of space and light. Forbs greatly contribute to plant richness in the studied system (Fidelis et al. 2012) and their presence in the aboveground vegetation is reduced when disturbances are absent (Overbeck et al. 2005), as we observed in the 2015 data. Bud bank of forbs is highly negatively affected by exclusion of disturbances over longer periods (Fidelis et al. 2014). Thus reintroduction of typical forbs populations appears to be a challenge in grasslands abandoned for long periods of time.

Differently than expected, mowing did not reduce cover of the dominant species A. lateralis. This species has great capacity to adapt to a wide range of management intensities (Carvalho et al. 2009), being also dominant in grazed areas along the study region (Andrade et al. 2016). However, mowing reduced its height and, consequently, its aboveground biomass. As expected, plots with lower $A$. lateralis cover (Fig. 1A) and lower vegetation height had higher diversity (Fig. 1B), corroborating with previous knowledge (Bond \& Keeley 2005; Overbeck et al. 2005). For purposes of easy monitoring and facilitation of management decision in these grasslands, to focus on vegetation height thus may be helpful. Interestingly, this may be the case not only for abandonment situation, as in our study, but also for the opposite case: restoration of grasslands under overgrazing, i.e., where high grazing pressure leads to a very short height and causes biodiversity losses (Fedrigo et al. 2017). In our study, vegetation height was the variable that responded more quickly than cover of dominant grass species. During the rather short period of our experiment, application of mowing two or three times apparently did not cause any difference; further and long-term studies are important to get information on the most efficient treatment on the long run.
Unlike temperate grasslands, where hay transfer has shown good results (Kiehl \& Wagner 2006; Klimkowska et al. 2010; Knut et al. 2010; Schmiede et al. 2012), in our experiment we did not manage to reintroduce species by this technique. Hay transfer was also not efficient for restoration in another recent restoration experiment in Campos Sulinos region (Thomas 2019), in Cerrado savannas (Pilon et al. 2018) and in Campos Rupestres grasslands (Stradic et al. 2013). Related reasons are still not entirely clear and could include unfavorable site conditions, lack of viable seeds in the hay, or presence of dormancy in seeds (Stradic et al. 2013). We did not control the germination of seeds contained in the hay, so we cannot affirm which one of the three reasons is the major cause of these unsatisfactory results. In our case, the high cover of the dominant grass may also have contributed to the lack of germination. At any rate, based on our results and on Stradic et al. (2013) and Pilon et al. (2018), hay transfer seems to be an ineffective technique for restoration projects in subtropical and tropical grasslands. However, the number of studies still is small for generalizations, and the technique should be tested over a broader range of sites and varying procedures of hay introduction (e.g. season, frequency, amount). Further, interactions with other factors, including disturbances, need to be analyzed more specifically. Importantly, a recent study has shown that in the highland grasslands, the seed bank is small and had little relevance for recovery after disturbances (MS Vieira, GE Overbeck unpubl. res.), reinforcing the need of experiments evaluating species introduction techniques.

Overall, our experiment, one of the first active restoration experiments in the South Brazilian highland grasslands, clearly indicates that the reintroduction of disturbances by mowing is an efficient and fast way to increase plant species richness and diversity in abandoned grasslands. The study contributes to the ongoing debate on the question of management for biodiversity conservation and restoration in Southern Brazil (Luza et al. 2016; Overbeck et al. 2016; 2018) and emphasizes the potential of active management for conservation purposes. In our case, working in abandoned grassland, management reintroduction contributed to increase plant diversity. In opposite situations, in overgrazed grassland, it can be the contrary: reduced management intensity can lead to grassland recovery (Fedrigo et al. 2017). This means that management actions always need adequate monitoring of their effects, but also that we should discuss specific treatments - even if polemic, e.g. the use of fire - based on effects.

Species introduction still is a large challenge in ecological restoration projects and requires a better development of suitable techniques. A better understanding of the filters that limit species establishment at degraded sites will helps us to implement management actions that will favor desired species (Thomsen \& D'Antonio 2007; Funk et al. 2008; Hulvey \& Aigner 2014) and allow us to select species with 


\section{Pedro Augusto Thomas, Gerhard Ernst Overbeck and Sandra Cristina Müller}

greater probability to establish themselves when working with species reintroduction (Grman et al. 2015). We recommend that further research activities focus on the questions of seed availability/limitation, seed dispersal and plant establishment in a restoration context.

\section{Acknowledgements}

We thank to Pedro Abreu Ferreira and the IMA-PUCRS for the possibility to conduct this study on CPCN PróMata. This work was supported by CNPq (grant numbers 477618/2013-8). Gerhard Ernst Overbeck and Sandra Cristina Müller received CNPq productivity grants (310022/2015-0 and 309874/2015-7). This study is part of the research of the PPBio Network Campos Sulinos (MCTIC/ CNPq). Pedro Augusto Thomas acknowledges CNPq and MCTIC for scholarships. This study was financed in part by CAPES - Finance Code 001.

\section{References}

Andrade BO, Bonilha CL, Ferreira PMA, Boldrini II, Overbeck GE. 2016. Highland grasslands at the southern tip of the Atlantic Forest biome: Management options and conservation challenges. Oecologia Australis 20: 37-61.

Andrade BO, Bonilha CL, Overbeck GE. et al. 2019. Classification of South Brazilian grasslands: Implications for conservation. Applied Vegetation Science 22: 168-184.

Baldissera R, Fritz L, Rauber R, Müller SC. 2010. Comparison between grassland communities with and without disturbances. Neotropical Biology and Conservation 5: 3-9.

Boldrini II, Eggers L. 1996. Vegetação campestre do sul do Brasil: dinâmica de espécies à exclusão do gado. Acta Botanica Brasilica 10: 37-50.

Bond WJ. 2016. Ancient grasslands at risk. Science 351: 120-122.

Bond WJ, Keeley JE. 2005. Fire as a global 'herbivore': the ecology and evolution of flammable ecosystems. Trends in Ecology and Evolution 20: 387-394.

Carvalho PCF, Santos DT, Gonçalves EN, et al. 2009. Lotação animal em pastagens naturais: políticas, pesquisas, preservação e produtividade. In.: Pillar VP, Müller SC, Castilhos ZMS, Jacques AVA. (eds.) Campos Sulinos: conservação e uso sustentável da biodiversidade. Brasília, MMA. p. 214-228

Fedrigo JK, Ataide PF, Azambuja Filho J, et al. 2017. Temporary grazing exclusion promotes rapid recovery of species richness and productivity in a long-term overgrazed Campos grassland. Restoration Ecology 26: 677-685

Fidelis A, Appezzato-da-Glória B, Pillar VD, Pfadenhauer J. 2014. Does disturbance affect bud bank size and belowground structures diversity in Brazilian subtropical grasslands? Flora 209: 110-116.

Fidelis A, Blanco CC, Müller SC, Pillar VD, Pfadenhauer J. 2012. Short-term changes caused by fire and mowing in Brazilian Campos grasslands with different long-term fire histories. Journal of Vegetation Science 23: 552-562.

Funk JL, Cleland EE, Suding KN, Zavaleta ES. 2008. Restoration through reassembly: plant traits and invasion resistance. Trends in Ecology and Evolution 23: 695-703.

Grman E, Bassett T, Zirbel1 CR, Brudvig LA. 2015. Dispersal and establishment filters influence the assembly of restored prairie plant communities. Restoration Ecology 23: 892-899.

Guido A, Salengue E, Dresseno A. 2017. Effect of shrub encroachment on vegetation communities in Brazilian forest-grassland mosaics. Perspectives in Ecology and Conservation 15: 52-55.
Hulvey KB, Aigner PA. 2014. Using filter-based community assembly models to improve restoration outcomes. Journal of Applied Ecology 51: 997-1005.

Kiehl K, Kirmer A, Donath TW, Rasran L, Hölzel N. 2010. Species introduction in restoration projects - Evaluation of different techniques for the establishment of semi-natural grasslands in Central and Northwestern Europe. Basic and Applied Ecology 11: 285-299.

Kiehl K, Wagner C. 2006. Effect of hay transfer on long-term establishment of vegetation and grasshoppers on former arable fields. Restoration Ecology 14: 157-166.

Klimkowska A, Kotowski W, Diggelen R, Grootjans AP, Dzierza P, Brzezinska K. 2010. Vegetation re-development after fen meadow restoration by topsoil removal and hay transfer. Restoration Ecology 18: 924-933.

Knut R, Jørn-Frode N, Ingvild A, Inger A, Einar H. 2010. Recreating semi-natural grasslands: A comparison of four methods. Ecological Engineering 36: 1672-1679.

Koch C, Conradi T, Gossner MM, et al. 2016. Management intensity and temporary conversion to other land-use types affect plant diversity and species composition of subtropical grasslands in southern Brazil. Applied Vegetation Science 19: 589-599.

Koyama A, Koyanagi TF, Akasaka M, Takada M, Okabe M. 2017. Combined burning and mowing for restoration of abandoned semi-natural grasslands. Applied Vegetation Science 20: 40-49.

Londo G. 1976. The decimal scale for releves of permanent quadrats. Vegetatio 33: 61-64.

Luza AL, Gonçalves GL, Pillar VP, Hartz SM. 2016. Processes related to habitat selection, diversity and niche similarity in assemblages of non-volant small mammals at grassland-forest ecotones. Natureza \& Conservação 4: 88-98.

Maccherini S, Santi E. 2012. Long-term experimental restoration in a calcareous grassland: Identifying the most effective restoration strategies. Biological Conservation: 146: 123-135.

Manly BFJ. 2007. Randomization, bootstrap, and Monte Carlo methods in biology. 3rd edn. Boca Raton, Chapman \& Hall/ CRC.

Maron JL, Jefferies RL. 2001. Restoring enriched grasslands: effects of mowing on species richness, productivity, and nitrogen retention. Ecological Applications 11: 1088-1100.

Nagata YK, Ushimaru A. 2016. Traditional burning and mowing practices support high grassland plant diversity by providing intermediate levels of vegetation height and soil $\mathrm{pH}$. Applied Vegetation Science 19: 567-577.

Oksanen J, Blanchet FG, Friendly M, et al. 2017. vegan: Community Ecology Package. R package version 2.4-3. https://CRAN.R-project. org/package= =egan

Overbeck GE, Ferreira PMA, Pillar VD. 2016. Conservation of mosaics calls for a perspective that considers all types of mosaic-patches. Reply to Luza et al. Natureza \& Conservação 14: 152-154.

Overbeck GE, Müller SC, Fidelis A, et al. 2007 Brazil's neglected biome: The South Brazilian Campos. Perspectives in Plant Ecology, Evolution and Systematics 9: 101-116.

Overbeck GE, Müller SC, Pillar VD, Pfadenhauer J. 2005. Fine-scale postfire dynamics in southern Brazilian subtropical grassland. Journal of Vegetation Science 16: 655-664.

Overbeck GE, Scasta JD, Furquim FF, Boldrini II, Weir JR. 2018. The South Brazilian grasslands - a South American Tallgrass Prairie? Parallels and implications of fire dependency. Perspectives in Ecology and Conservation 16: 24-30

Packard S, Ross LM. 2005. Restoring remants. In: Packard S, Mutel CL. (eds.) The tallgrass restoration handbook: for prairies, savannas and woodlands. Washington, Island Press. p. 98-117

Pillar VD, Vélez E. 2010. Extinção dos Campos Sulinos em Unidades de Conservação: um fenômeno natural ou um problema ético? Natureza \& Conservação 8: 84-86.

Pilon NAL, Buisson E, Durigan G. 2018. Restoring Brazilian savanna ground layer vegetation by topsoil and hay transfer. Restoration Ecology 26: 73-81.

R Development Core Team 2016. R: A language and environment for statistical computing. Vienna, R Foundation for Statistical Computing. 


\section{Restoration of abandoned subtropical highland grasslands in Brazil: mowing produces fast effects, but hay transfer does not}

Schmiede R, Otte A, Donath TW. 2012. Enhancing plant biodiversity in species-poor grassland through plant material transfer - the impact of sward disturbance. Applied Vegetation Science 15: 290-298.

Stradic S, Buisson E, Fernandes GW. 2013. Restoration of Neotropical grasslands degraded by quarrying using hay transfer. Applied Vegetation Science 17: 482-492.

Thomas PA, Schüler J, Boavista LDR, Torchelsen FP, Overbeck GE, Müller SC. 2019. Controlling the invader Urochloa decumbens: Subsidies for ecological restoration in subtropical Campos grassland. Applied Vegetation Science 22: 96-104.
Thomsen MA, D'Antonio CM. 2007. Mechanisms of resistance to invasion in a California grassland: the roles of competitor identity, resource availability, and environmental gradients. Oikos 116: 17-30.

Török P, Vida E, Deák B, Lengyel S, Tóthmérész B. 2011. Grassland restoration on former croplands in Europe: an assessment of applicability of techniques and costs. Biodiversity and Conservation 20: 2311-2332.

Veldman JW, Buisson E, Durigan G, et al. 2015. Toward an old-growth concept for grasslands, savannas, and woodlands. Frontiers in Ecology and the Environment 13: 154-162. 